\title{
Stachybotrys-like taxa from karst areas and a checklist of stachybotrys-like species from Thailand
}

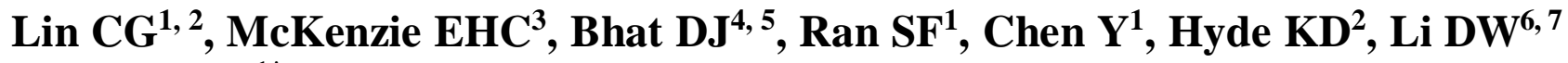 and Wang $\mathbf{Y}^{1^{*}}$}

${ }^{1}$ Department of Plant Pathology, College of Agriculture, Guizhou University, Guiyang, Guizhou 550025, China

${ }^{2}$ Center of Excellence in Fungal Research, Mae Fah Luang University, Chiang Rai, 57100, Thailand

${ }^{3}$ Landcare Research, Auckland, New Zealand

${ }^{4}$ Formerly, Department of Botany, Goa University, Goa, India

${ }^{5}$ No. 128/1-J, Azad Housing Society, Curca, Goa Velha 403108, India

${ }^{6}$ The Connecticut Agricultural Experiment Station Valley Laboratory, 153 Cook Hill Road, Windsor, CT 06095, USA

${ }^{7}$ Co-Innovation Center for Sustainable Forestry in Southern China, Nanjing Forestry University, Nanjing, Jiangsu 210037, China

Lin CG, McKenzie EHC, Bhat DJ, Ran SF, Chen Y, Hyde KD, Li DW, Wang Y 2016 Stachybotrys-like taxa from karst areas and a checklist of stachybotrys-like species from Thailand. Mycosphere 7(9), 1273-1291, Doi 10.5943/mycosphere/7/9/3

\begin{abstract}
During a survey of hyphomycetes from karst areas in Thailand, four stachybotrys-like taxa, viz., Cymostachys garethjonesii sp. nov., Memnoniella oblongispora sp. nov., M. nilagirica comb. nov. and Stachybotrys microspora were identified and are provided with descriptions in this paper. The new species are introduced based on morphological and molecular differences and compared with similar or related taxa. Memnoniella nilagirica and Stachybotrys microspora are new records for Thailand. An annotated checklist of stachybotrys-like taxa in Thailand is provided based on previous publications and database searches.
\end{abstract}

Key words - karst - new species - phylogeny - Stachybotryaceae - taxonomy

\section{Introduction}

The family Stachybotryaceae, typified by Stachybotrys Corda, was established by Crous et al. (2014) to accommodate Myrothecium Tode, Peethamabra Subram. \& Bhat and Stachybotrys Corda. Maharachchikumbura et al. $(2015,2016)$ accepted four additional genera Albosynnema E.F. Morris, Parasarcopodium Melnik et al., Sarcopodium Ehrenb. and Scopinella Lév. within this family, based on morphological features and phylogenetic analysis. Lombard et al. (2016) revised this family by combining morphology and multi-locus phylogenetic analyses using cmdA, ITS, rpb2, tef1 and tub2 datasets. Presently, 33 genera are accepted in the family Stachybotryaceae (Lombard et al. 2016).

The genus Stachybotrys (Stachybotryaceae, Hypocreales) was established by Corda (1837) to accommodate Stachybotrys atra Corda 1837 (now known as S. chartarum (Ehrenb.) S. Hughes 1958) (Bisby 1943, Seifert et al. 2011). Stachybotrys is characterized by macronematous, mononematous, branched or unbranched conidiophores, with discrete, determinate, terminal, phialidic conidiogenous cells, with unicellular, smooth or variously ornamented conidia, produced in a slimy mass or in chains (Ellis 1971, Jong \& Davis 1976, Pinruan et al. 2004b, Seifert et al. 
2011, Wang et al. 2015). The genus Stachybotrys is widely distributed, and can commonly be found on damp paper, cotton, linen, soil and decaying plant material, and cellulose-based building material, such as drywall and wall paper in indoor environments (Ellis 1971, 1976, Whitton et al. 2001, Tang et al. 2003, Li \& Yang 2004, Thongkantha et al. 2008, Izabel et al. 2010, Jie et al. 2013, Wang et al. 2015).

The genus Memnoniella Höhn. and Stachybotrys were considered to be separate genera (Bisby 1945, Jong \& Davis 1976), however, Wang et al. (2015) reevaluated these genera based on morphology and phylogeny, and proposed Memnoniella as a synonym of Stachybotrys, the latter with 75 accepted species. However, Lombard et al. (2016) resurrected Memnoniella following combined morphology and multi-locus phylogenetic analyses using $c m d A$, ITS, rpb2, tefl and tub2.

The genus Cymostachys L. Lombard \& Crous, typified by $C$. fabispora L. Lombard \& Crous, was established by Lombard et al. (2016) to accommodate two stachybotrys-like species, $C$. coffeicola L. Lombard \& Crous and C. fabispora L. Lombard \& Crous, with irregularly cymosely branched conidiophores and olivaceous brown to dark brown, fabiform conidia.

Karst is the term used to describe a special style of landscape containing caves and extensive underground water systems that is developed on especially soluble rocks, such as limestone, marble, and gypsum (Ford \& Williams 2007). Such areas are characterized by sinking streams, caves, enclosed depressions, fluted rock outcrops, and large springs (Ford \& Williams 2007). A huge number of fungi, bacteria, lichen, algae and other microorganisms are present in the karst areas, and play an important role in karstification processes, especially the weathering and dissolution of carbonate rocks (Viles 1984, Lian et al. 2008).

During a survey of hyphomycetes from karst areas in Thailand, four stachybotrys-like species were identified and are described in this paper. Two are new species in the genera Cymostachys and Memnoniella; one is new combination and two are new records for Thailand. In addition, an annotated checklist of stachybotrys-like fungi in Thailand is provided based on previous publications and databases.

\section{Materials \& Methods}

\section{Collection and isolation of fungi}

Dead litter (stems, wood, and leaves) from a variety of plants were collected during May to August 2015 from four karst areas in Thailand, viz., (1) Pha Chang (1949'52.44", 10001'30.64), Wiang Chai District, Chiang Rai Province; (2) Ang Kep Nam Wat Tham Khao Hin Phayanak (Wat

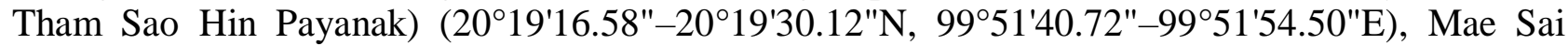

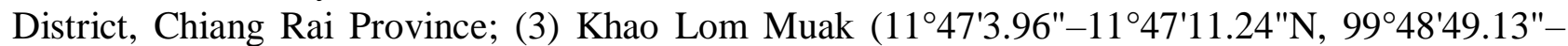

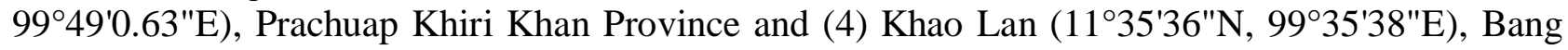
Saphan District, Prachuap Khiri Khan Province. Samples were taken to the laboratory in Zip-lock plastic bags for examination. The specimens were incubated in sterile moist chambers and examined from time to time using a stereo microscope (Motic SMZ 168). Fungi were removed with a needle and placed in a drop of distilled water on a slide for morphological study. Photographs of fungal structures were captured using a Nikon ECLIPSE 80i compound microscope with a Canon 450D digital camera. All measurements were made by Tarosoft (R) Image FrameWork program. Photo plates were made with Adobe Photoshop CS6 Extended version 13.0.1 (Adobe Systems, USA). Isolation onto potato dextrose agar (PDA) or malt extract agar (MEA) was performed by single spore isolation method (Chomnunti et al. 2014). Herbarium material is deposited in the herbarium of Mae Fah Luang University (MFLU), Chiang Rai, Thailand. Cultures are deposited at Mae Fah Luang University Culture Collection (MFLUCC) and International Collection of Microorganisms from Plants (ICMP). Faces of fungi numbers are given for the reference specimens as explained in Jayasiri et al. (2015). 
Table 1 GenBank accession numbers of isolates included in this study

\begin{tabular}{|c|c|c|c|c|c|c|}
\hline Species & Isolate number $^{\mathrm{a}}$ & cmdA & ITS & $r p b 2$ & tef1 & tub2 \\
\hline Cymostachys coffeicola & CBS 252.76 & KU846035 & KU846052 & KU846081 & KU846097 & KU846113 \\
\hline C. coffeicola & СРC 25009 & $-^{\mathrm{b}}$ & KU846053 & - & - & - \\
\hline C. fabispora & CBS $136180=$ MUCL $39004=$ INIFAT C93/322 & KU846036 & KU846054 & KU846082 & KU846098 & KU846114 \\
\hline C. fabispora & CPC 24352 & - & KU846055 & KU846083 & KU846099 & - \\
\hline C. garethjonesii & MFLUCC 16-0028 & - & KU760375 & KU760395 & - & KY124126 \\
\hline $\begin{array}{l}\text { Memnoniella } \\
\text { brunneoconidiophora }\end{array}$ & CBS 109477 & - & KU846138 & KU846192 & KU846218 & KU846243 \\
\hline M. brunneoconidiophora & CBS $136191=$ MUCL 43313 & KU846116 & KU846139 & KU846193 & KU846219 & KU846244 \\
\hline M. dichroa & ATCC $18913=$ IMI 61337 & - & AF081472 & - & - & - \\
\hline M. dichroa & CBS $526.50=$ ATCC $18917=$ IMI $017506=$ MUCL 9482 & KU846117 & KU846140 & KU846194 & KU846220 & - \\
\hline M. dichroa & CBS 123800 & KU846118 & KU846141 & KU846195 & KU846221 & - \\
\hline M. echinata & CBS 216.32 & KU846119 & KU846142 & KU846196 & KU846222 & KU846245 \\
\hline M. echinata & CBS 304.54 & KU846120 & KU846143 & KU846197 & KU846223 & - \\
\hline M. echinata & CBS 343.50 & KU846121 & KU846144 & KU846198 & KU846224 & KU846246 \\
\hline M. echinata & CBS 344.39 & KU846122 & KU846145 & KU846199 & KU846225 & KU846247 \\
\hline M. echinata & CBS 406.80 & KU846123 & KU846146 & KU846200 & KU846226 & KU846248 \\
\hline M. echinata & CBS $627.66=$ IMI $045547=$ NRRL 2181 & KU846124 & KU846147 & KU846201 & KU846227 & KU846249 \\
\hline M. echinata & DAOMC 173162 & KU846125 & JN942886 & KU846202 & KU846228 & KU846250 \\
\hline M. echinata & DAOMC 235365 & KU846126 & KU846149 & KU846203 & KU846229 & KU846251 \\
\hline M. ellipsoidea & CBS $136199=$ MUCL 39088 & KU846127 & KU846150 & KU846204 & KU846230 & KU846252 \\
\hline M. ellipsoidea & CBS $136200=$ MUCL 39089 & KU846128 & KU846151 & KU846205 & KU846231 & KU846253 \\
\hline M. ellipsoidea & CBS 136201 = MUCL 39090 & KU846129 & KU846152 & KU846206 & KU846232 & KU846254 \\
\hline M. ellipsoidea & CBS $136202=$ MUCL 41876 & - & KU846153 & KU846207 & KU846233 & KU846255 \\
\hline M. humicola & CBS 463.74 & KU846130 & KU846154 & KU846208 & KU846234 & - \\
\hline M. longistipitata & ATCC 22699 & - & AF081471 & - & - & - \\
\hline M. longistipitata & CBS $136197=$ MUCL 33065 & KU846131 & KU846155 & KU846209 & KU846235 & KU846256 \\
\hline M. nilagirica & MFLUCC $15-0660$ & KY124122 & KU760374 & KU760394 & - & - \\
\hline M. oblongispora & MFLUCC 15-1074 & KY124123 & KU760376 & KU760396 & - & KY124127 \\
\hline M. oenanthes & ATCC $22844=$ IMI 016185 & - & AF081473 & - & - & - \\
\hline M. oenanthes & CBS $388.73=$ ATCC 32255 & - & KU846156 & KU846210 & KU846236 & - \\
\hline M. pseudonilagirica & CBS $\mathbf{1 3 6 4 0 5}=$ MUCL 39120 & KU846132 & KU846157 & KU846211 & KU846237 & KU846257 \\
\hline
\end{tabular}




\begin{tabular}{|c|c|c|c|c|c|c|}
\hline Species & Isolate number $^{\mathrm{a}}$ & cmdA & ITS & $r p b 2$ & tef1 & tub2 \\
\hline M. putrefolia & CBS 101177 & - & KU846158 & KU846212 & KU846238 & KU846258 \\
\hline M. putrefolia & CBS $136171=$ MUCL $41166=$ INIFAT C98/65-2 & KU846133 & KU846159 & KU846213 & KU846239 & KU846259 \\
\hline Peethambara sundara & CBS 646.77 & - & KU846471 & KU846509 & KU846531 & KU846551 \\
\hline Stachybotrys aloeticola & CBS $137940=$ CPC 19705 & KU846570 & KJ817888 & KU846901 & - & KJ817886 \\
\hline S. aloeticola & CBS $137941=$ CPC 19706 & KU846571 & KJ817889 & KU846902 & - & KJ817887 \\
\hline S. chartarum & CBS 182.80 & KU846573 & KU846679 & KU846904 & KU847003 & KU847115 \\
\hline S. chartarum & CBS 363.49 & KU846575 & KU846681 & KU846906 & KU847005 & KU847117 \\
\hline S. chartarum & CBS 119366 & KU846591 & KU846697 & KU846922 & KU847021 & KU847132 \\
\hline S. chartarum & CBS 119369 & KU846592 & KU846698 & KU846923 & KU847022 & KU847133 \\
\hline S. chartarum & CBS 119370 & KU846593 & KU846699 & KU846924 & KU847023 & KU847134 \\
\hline S. chartarum & CBS 119371 & KU846594 & KU846700 & KU846925 & KU847024 & KU847135 \\
\hline S. chlorohalonata & CBS 109283 & KU846622 & KU846728 & KU846953 & KU847052 & KU847163 \\
\hline S. chlorohalonata & CBS 109285 & KU846623 & KU846729 & KU846954 & KU847053 & KU847164 \\
\hline S. chlorohalonata & CBS $136158=$ MUCL 49910 & KU846626 & KU846732 & KU846956 & KU847056 & KU847167 \\
\hline S. limonispora & CBS 128809 & KU846629 & KU846735 & KU846959 & KU847058 & KU847170 \\
\hline S. limonispora & CBS $136165=$ MUCL 18730 & KU846630 & KU846736 & KU846960 & KU847059 & KU847171 \\
\hline S. microspora & MFLUCC 15-0830 & KY124124 & KU760377 & KU760397 & KU760392 & KY124128 \\
\hline S. microspora & MFLUCC 15-1076 & KY124125 & KU760378 & KU760398 & KU760393 & KY124129 \\
\hline S. microspora & ATCC 18852 = IMI 124902 & - & AF081475 & - & - & - \\
\hline S. microspora & CBS 186.79 & KU846631 & KU846737 & DQ676580 & KU847060 & KU847172 \\
\hline S. phaeophialis & KAS 525 & KU846632 & KU846738 & KU846962 & KU847061 & KU847173 \\
\hline S. reniformis & ATCC 18839 & - & AF081476 & - & - & - \\
\hline S. reniformis & CBS 976.95 & KU846633 & KU846739 & KU846963 & KU847062 & KU847174 \\
\hline S. reniformis & CBS $136198=$ MUCL 39087 & - & KU846740 & - & KU847063 & - \\
\hline S. subsylvatica & CBS 126205 & KU846634 & KU846741 & KU846964 & KU847064 & KU847175 \\
\hline Striatobotrys atypica & CBS $141059=$ CPC 18423 & KU846646 & KU846753 & KU846973 & KU847076 & KU847187 \\
\hline Stri. eucylindrospora & CBS 203.61 = ATCC 18851 = IMI $085334=$ MUCL 9483 & KU846648 & KU846755 & KU846975 & KU847078 & KU847189 \\
\hline Stri. humicola & CBS 102408 & KU846650 & KU846759 & KU846979 & KU847082 & KU847193 \\
\hline Stri. oleronensis & CBS 137258 & - & KF777192 & KU846980 & KU847083 & KU847194 \\
\hline Stri. rhabdospora & CBS 528.80 & KU846651 & KU846760 & KU846981 & KU847084 & KU847195 \\
\hline Stri. yисcаe & CBS 390.68 & KU846657 & KU846770 & KU846989 & KU847093 & KU847205 \\
\hline
\end{tabular}


ATCC, American Type Culture Collection, Manassas, United States; CBS, Centraalbureau voor Schimmelcultures, Utrecht, Netherlands; CPC, Culture collection of Pedro Crous, housed at CBS; DAOM, Canadian Collection of Fungal Cultures, Agriculture and Agri-Food Canada, Ottawa, Canada; IMI, International Mycological Institute, CABIBioscience, Egham, Bakeham Lane, UK; INIFAT, INIFAT Fungus Collection, Ministerio de Agricultura Habana, Cuba; KAS, Collection of K.A. Seifert; MUCL, Mycothèque de l'Université Catholique de Louvian, Belgium; NRRL, Agricultural Research Service Culture Collection, Peoria, Illinois, United States.

${ }^{a}$ Ex-type and ex-epitype cultures are in bold

${ }^{\mathrm{b}}$ No data in GenBank.

\section{DNA extraction, PCR amplification and sequencing}

Genomic DNA was extracted from fungal mycelia grown on PDA or MEA at room temperature with the Fungal gDNA Kit (BioMIGA, USA) according to the manufacturer's instructions. The internal transcribed spacer region of ribosomal DNA (ITS), small subunit nuclear ribosomal DNA (SSU), large subunit nuclear ribosomal DNA (LSU), RNA polymerase II second largest subunit (rpb2), calmodulin ( $c m d \mathrm{~A})$ and $\beta$-tubulin (tub2) genes were amplified via polymerase chain reaction (PCR) using the following primers: ITS5 and ITS4 (White et al. 1990) for ITS, NS1 and NSS4 (White et al. 1990) for SSU, LROR and LR5 (Vilgalys \& Hester 1990) for LSU, rpb2H-6F2 and rpb2H-7R2 (Koster et al. 2009) for rpb2, CAL-228F and CAL2Rd for camA (Carbone \& Kohn 1999, Groenewald et al. 2013), and Bt2a and Bt2b for tub2 (Glass \& Donaldson 1995). The PCR products were sequenced with the same primers.

\section{Phylogenetic analyses}

Original sequences from the sequencing company were checked using BioEdit version 7.0.5.3 (Hall 1999). Most of the sequences were obtained from GenBank based on previous publications Lombard et al. (2016). The remaining homogenous sequences were obtained by BLAST searches (Altschul et al. 1990) of sequences in GenBank. All sequences used in this study are listed in Table 1. Alignments for each locus were done in MAFFT v7.212 (Katoh \& Standley 2013) and manually verified in MEGA 6.06 (Tamura et al. 2013). Conserved blocks were selected from the initial alignments with Gblocks 0.91b (Castresana 2000). The interleaved NEXUS files were formatted with PAUP*4.0b10 (Swofford 2002) and manually formatted for Bayesian inference analyses. Bayesian inference (BI), maximum parsimony (MP) and maximum likelihood (ML) were used in this study for phylogenetic analyses. For Bayesian inference analysis, the best model of evolution was determined using MrModeltest v2 (Nylander 2004). Bayesian inference analysis was done with MrBayes v 3.2.5 (Ronquist et al. 2012). Maximum parsimony analysis was performed in PAUP*4.0b10 (Swofford 2002). Maximum likelihood analysis was performed in raxmlGUI v 1.3.1 (Silvestro \& Michalak 2012). Phylogenetic trees were drawn with TreeView 1.6.6 (Page 1996).

\section{Annotated checklist}

An annotated checklist of the genus Stachybotrys in Thailand was made based on previous publications (Jeamjitt et al. 2006, Pinnoi et al. 2006, Bhilabutra et al. 2010) and the USDA fungal database (Farr \& Rossman 2015). The host/substrate and location information are included in this list.

\section{Results}

\section{Phylogenetic analyses}

The aligned sequence matrix comprises $c m d$ A (774 bp), ITS (612 bp), rpb2 (721 bp), tef1 (643 bp) and tub2 (433 bp) sequence data for 28 taxa and one outgroup taxon with a total of 3183 total characters, of which 1181 are parsimony informative, 205 are parsimony uninformative, and 1797 characters are constant. The result of maximum parsimony (MP) analysis based on combined $c m d A$, ITS, rpb2, tef1 and tub2 sequence data is shown in Fig. 1. 


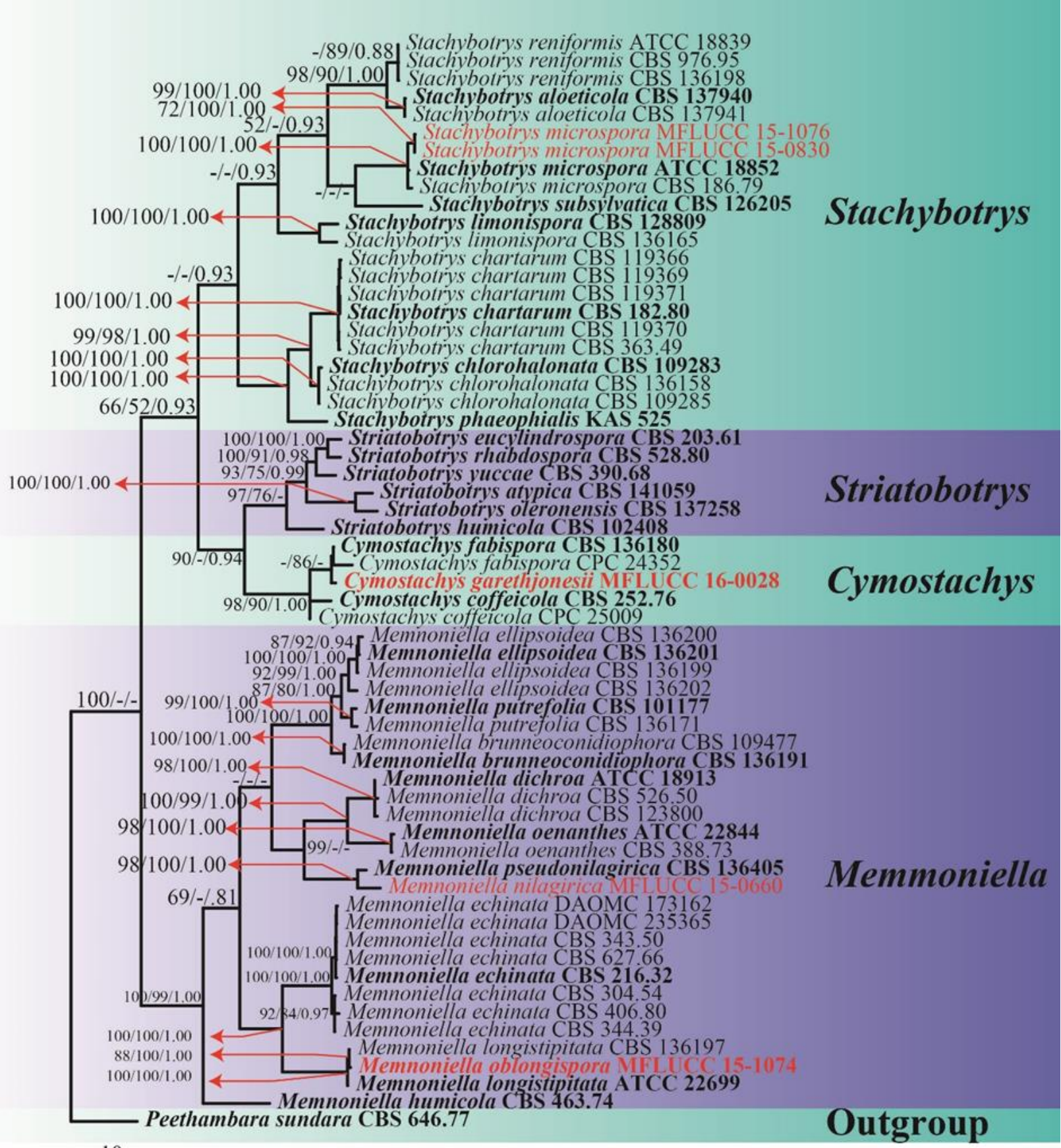

10

Fig. 1 - Phylogenetic tree generated from maximum parsimony (MP) analysis based on combined $c m d A$, ITS, rpb2, tef1 and tub2 sequence data for selected genera within the family Stachybotryaceae. Bootstrap support values for maximum parsimony (MP) and maximum likelihood (ML) greater than 50\% and Bayesian posterior probabilities greater than 0.8 are indicated above or below the nodes as MPBS/MLBS/PP. The ex-type strains are in bold and the new isolates are in red. The tree is rooted with Peethambara sundara (CBS 646.77).

In the present study, we found that the strains of S. microspora (MFLUCC 15-1076 and MFLUCC 15-0830) form a clade together with the strain of S. microspora (ATCC 18852 and CBS 186.79) with 100\% MP bootstrap support, 100\% ML bootstrap support and 100\% Bayesian posterior probabilities, sister to $S$. subsylvatica (CBS 126205). Cymostachys garethjonesii (MFLUCC 16-0028) forms a well-supported clade (BSMP $=98 \%$, BSML $=90 \%$, BYPP $=1.00$ ) with C. fabispora (CBS 136180 and CPC 24352) and C. coffeicola (CBS 252.76 and CPC 25009), 
sister to the Striatobotrys clade. Memnoniella oblongispora (MFLUCC 15-1074) and the ex-type strain of $M$. longistipitata (ATCC 22699) grouped together with BSMP $=100 \%$, BSML $=100 \%$ and BYPP $=1.00$. Memnoniella nilagirica (MFLUCC 15-0660) forms a clade with the strain of $M$. pseudonilagirica (CBS 136405) with 98\% MP bootstrap support, 100\% ML bootstrap support and $100 \%$ Bayesian posterior probabilities.

\section{Taxonomy}

Four stachybotrys-like taxa were identified and are described below.

Cymostachys garethjonesii C.G. Lin, Yong Wang bis \& K.D. Hyde, sp. nov.

Fig. 2 Index Fungorum number - IF 552555

Facesoffungi number - FoF 02017

Etymology - Named in honour of Professor E.B. Gareth Jones for his immense contribution to marine and tropical mycology.

Holotype - MFLU 15-3272

Colonies on PDA effuse, hairy to powdery, circular, grey to orange on top side and reverse side, attaining a diameter of $2-2.5 \mathrm{~cm}$ in 20 days at $25^{\circ} \mathrm{C}$. Mycelium partly superficial and partly immersed. Sexual morph: Undetermined. Asexual morph: Hyphomycetous. Conidiophores macronematous, mononematous, caespitose, erect, irregularly cymosely branched, occasionally undulating at the upper part of branches, smooth or occasionally verruculose, thick-walled, septate, hyaline at the base, light grey at the apex, bearing at its apex a crown of 2-3(-4) phialides, up to $222 \mu \mathrm{m}$ long, $3-5 \mu \mathrm{m}(\bar{x}=3.6 \mu \mathrm{m}, \mathrm{n}=45)$ wide at the base, $1.5-3 \mu \mathrm{m}$ wide $(\bar{x}=2.3 \mu \mathrm{m}, \mathrm{n}=40)$ near the apex. Conidiogenous cells monophialidic, discrete, determinate, terminal, clustered at the apex of conidiophores, oval, obovoid, oblong, rarely verruculose, subhyaline to grey at the base, subhyaline to light grey at the middle part, dark grey to black at the apex, $6-10.5 \mu \mathrm{m}(\bar{x}=8.3 \mu \mathrm{m}, \mathrm{n}$ $=60)$ long, $3-5 \mu \mathrm{m}(\bar{x}=4.0 \mu \mathrm{m}, \mathrm{n}=50)$ wide at the widest point. Conidia aggregated in large, slimy, black and glistening heads, acrogenous, simple, reniform, fabiform, rounded at both ends, rough-walled, dark brown to black, unicellular, 5-9 $\mu \mathrm{m}(\bar{x}=7.0 \mu \mathrm{m}, \mathrm{n}=50)$ long, 3.5-6.5 $\mu \mathrm{m}(\bar{x}=$ $4.8 \mu \mathrm{m}, \mathrm{n}=50$ ) wide at the widest point.

Material examined - Thailand, Prachuap Khiri Khan, Bang Saphan District, Khao Lan, $11^{\circ} 35^{\prime} 36^{\prime \prime N} 99^{\circ} 35^{\prime} 38^{\prime \prime E}$, on decaying Dracaena sp. leaf, 29 July 2015, Chuan-Gen Lin, KLM 10-1 (MFLU 15-3272, holotype), ex-type living culture MFLUCC 16-0028.

Notes - In the phylogenetic tree generated from MP analysis based on combined $c m d A$, ITS, rpb2, tef1 and tub2 sequence data, Cymostachys garethjonesii (MFLUCC 16-0028) clusters within Cymostachys with good support (Fig. 1).

This new species is different from $C$. coffeicola and $C$. fabispora by having longer and narrower conidiophores, smaller conidiogenous cells, and slightly larger conidia. A crown of 2-3(4) phialides are borne at the apex of each conidiophore in the new species, whereas, the crown contains 2-6 phialides in C. coffeicola and C. fabispora. Cymostachys garethjonesii is similar to the description of S. sinuatophora in Matsushima (1971) and Wang et al. (2015) as both have reniform conidia and sometimes $C$. garethjonesii has undulating conidiophores. However, the conidiogenous cells of $C$. garethjonesii $(3-5 \mu \mathrm{m})$ are smaller than those of $S$. sinuatophora (5-7 $\mu \mathrm{m})$, and the conidia are also smaller $(5-9 \times 3.5-6.5 \mu \mathrm{m}$ vs. $8-12 \times 6-7 \mu \mathrm{m})$.

The most significant difference between $C$. garethjonesii and $S$. sinuatophora is the different branching of the conidiophores. Conidiophores of $C$. garethjonesii are irregularly cymosely branched, which is the distinct feature of the genus Cymostachys, while, conidiophores of $S$. sinuatophora are repeatedly, alternately branched. Jong and Davis (1976) proposed S. sinuatophora and $S$. reniformis as synonyms of $S$. nephrospora, however, Pinruan et al. (2004a), Wang et al. (2015) and Lombard et al. (2016) proposed S. sinuatophora to be a distinct species, because of its repeatedly, alternately branched, undulating to coiling conidiophores, which are not known for other stachybotrys-like species 


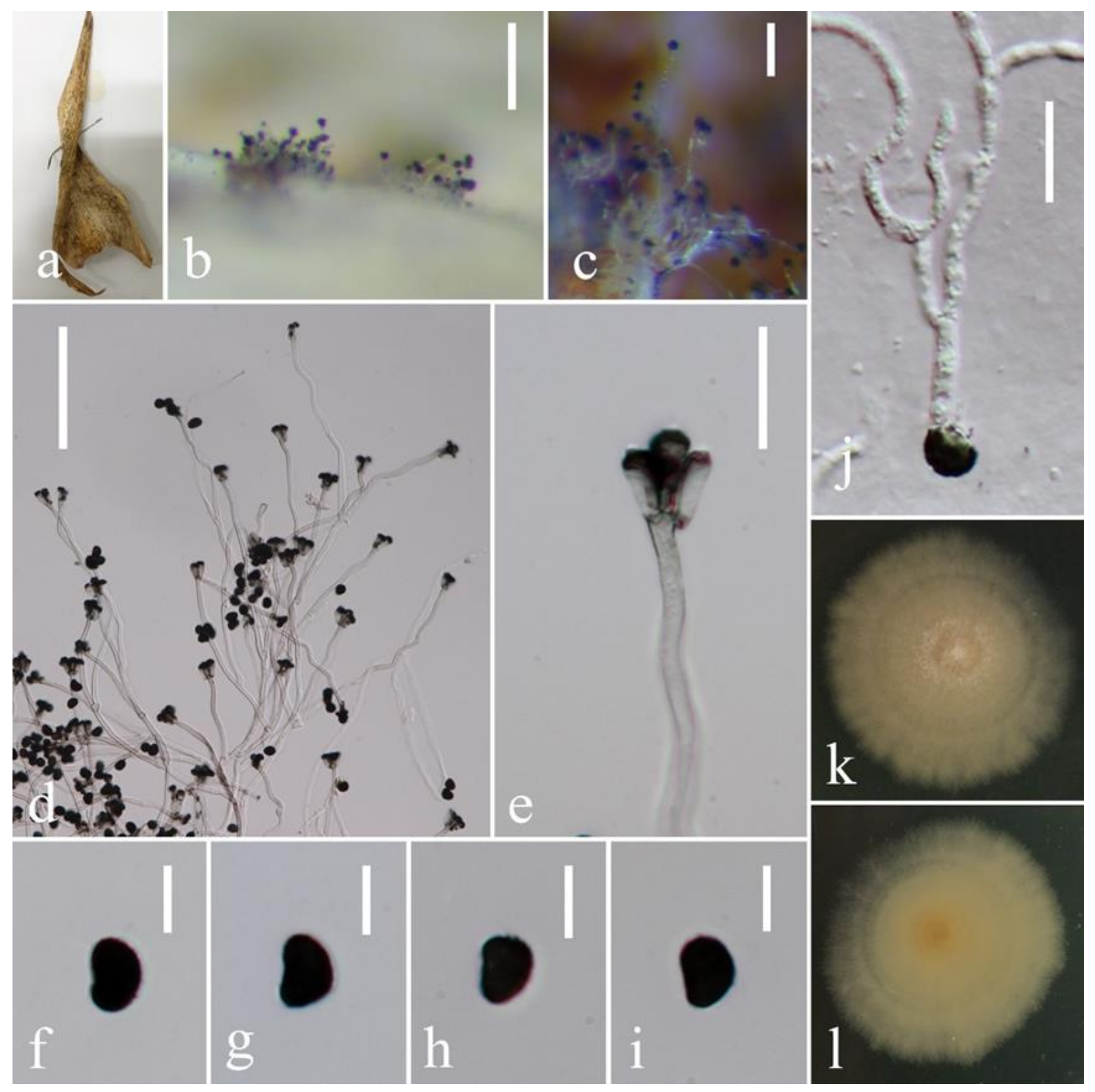

Fig. 2 - Cymostachys garethjonesii (MFLU 15-3272, holotype) a. Host leaves. b, c. Conidiophores on the host surface. d. Conidiophores and conidia. e. Conidiogenous cells. $\mathbf{f}-\mathbf{i}$. Conidia. j. Germinating conidium. k, l. 40-day old colonies on PDA, k from above, 1 from below. - Scale bars: $\mathrm{b}=200 \mu \mathrm{m}, \mathrm{c}-\mathrm{d}=100 \mu \mathrm{m}, \mathrm{e}, \mathrm{j}=20 \mu \mathrm{m}, \mathrm{f}-\mathrm{i}=10 \mu \mathrm{m}$.

Memnoniella oblongispora C.G. Lin, McKenzie, Yong Wang bis \& K.D. Hyde, sp. nov. $\quad$ Fig. 3 Index Fungorum number - IF 552085

Facesoffungi number - FoF 02081

Etymology - In reference to the oblong conidia.

Holotype - MFLU 15-3269

Colonies on PDA, effuse, gelatinous, circular, white to grey from center to the edge from above, light yellow to grey from center to the edge from below, attaining a diameter of $2.5-3.5 \mathrm{~cm}$ in 21 days at $25^{\circ} \mathrm{C}$. Mycelium partly superficial and partly immersed. Sexual morph: Undetermined. Asexual morph: Hyphomycetous. Conidiophores macronematous, mononematous, erect, simple, straight or flexuous, mostly unbranched, but sometimes branched, smooth, thickwalled, septate, bearing at its apex a crown of phialides, hyaline at the base, olive grey at the apex, 
85-180 $\mu \mathrm{m}(\bar{x}=125.6 \mu \mathrm{m}, \mathrm{n}=20)$ long, $6.5-12 \mu \mathrm{m}(\bar{x}=9.5 \mu \mathrm{m}, \mathrm{n}=20)$ wide at the base, tapering to $2.5-5 \mu \mathrm{m}(\bar{x}=3.9 \mu \mathrm{m}, \mathrm{n}=30)$ at the narrowest point near the apex, sometimes swelling again below the conidiogenous cells. Conidiogenous cells monophialidic, discrete, determinate, terminal, clustered at the apex of conidiophores, ellipsoidal, clavate, cylindrical, the outer ones somewhat curved, smooth, hyaline to olive green, 9-14 $\mu \mathrm{m}(\bar{x}=11 \mu \mathrm{m}, \mathrm{n}=40)$ long, 4-6.4 $\mu \mathrm{m}(\bar{x}=5 \mu \mathrm{m}, \mathrm{n}$ $=40$ ) wide at the widest point. Conidia aggregated in large, slimy, black and glistening heads, acrogenous, simple, oblong, verrucose, hyaline when young, olive green to black when mature, unicellular, 8.5-12 $\mu \mathrm{m}(\bar{x}=10.1 \mu \mathrm{m}, \mathrm{n}=80)$ long, 4.5-7 $\mu \mathrm{m}(\bar{x}=5.8 \mu \mathrm{m}, \mathrm{n}=80)$ wide at the widest point.

Material examined - THAILAND, Chiang Rai, Mae Sai District, Ang Kep Nam Wat Tham Khao Hin Phayanak (Wat Tham Sao Hin Payanak), 20¹9'16.58"-20¹9'30.12"N, 99 51'40.72"99 51'54.50"E, on decaying Quercus sp. leaf, 19 June 2015, Chuan-Gen Lin, WTSP 17-2 (MFLU 15-3269, holotype), ex-type living culture MFLUCC 15-1074.

Notes - Morphologically this species is most similar to M. dichroa (Grove) L. Lombard \& Crous, M. longistipitata D.W. Li, Chin S. Yang, Vesper \& Haugland and S. chartarum, but it can be distinguished from $M$. longistipitata and S. chartarum in having wider and rarely branched conidiophores. In addition, $M$. longistipitata can simultaneously produce both subsphaerical to sphaerical catenate conidia or oblong to ovoid conidia aggregated in slimy masses (Li et al. 2003). M. dichroa is similar to M. oblongispora in conidial size and shape (Bisby and Ellis 1949), but it has hyaline and unbranched conidiophores, while the conidiophores of $M$. oblongispora are olive grey at the apex and sometimes branched. Jong and Davis (1976) re-examined 50 strains of Stachybotrys and Memnoniella, including the culture of M. dichroa ATCC 18913, which was isolated by M. B. Ellis and further studied by Bisby \& Ellis (1949). Jong and Davis described the conidial shape of $M$. dichroa were ovate (Jong \& Davis 1976), whereas, the conidia of $M$. oblongispora are oblong.

From the phylogenetic trees of Bayesian inference (BI), maximum parsimony (MP) and maximum likelihood (ML) analyses based on combined $c m d A$, ITS, rpb2, tefl and tub2 sequence data (Fig. 1), this species is closest to M. longistipitata, however, it can be distinguished from $M$. longistipitata by the morphological characteristics outlined above.

Lombard et al. (2016) cited a strain (CBS 136197 = MUCL 33065) as M. longistipitata without a description. In our study, this strain was in the same clade as M. oblongispora with high support and we suggest that it is a second isolate of M. oblongispora.

Memnoniella nilagirica (Subram.) C.G. Lin, Yong Wang bis \& K.D. Hyde, comb. nov.

三Stachybotrys nilagirica Subram., Proc. Indian Acad. Sci., Pl. Sci. 46: 331 (1957)

Fig. 4

Index Fungorum number - IF 552556

Facesoffungi number - FoF 02016

Colonies on PDA effuse, hairy, white from above, light yellow from below, attaining a diameter of 5-7 cm in 30 days at $25^{\circ}$ C. Mycelium partly superficial and partly immersed. Sexual morph: Undetermined. Asexual morph: Hyphomycetous. Conidiophores macronematous, mononematous, erect, simple, straight or flexuous, rarely branched, smooth, thick-walled, septate, bearing at its apex a crown of phialides, hyaline at the base, olive grey at the apex, 185-350 $\mu \mathrm{m}$ long, 9-22 $\mu \mathrm{m}$ wide at the base, tapering to 4-6.5 $\mu \mathrm{m}$ near the apex. Conidiogenous cells monophialidic, discrete, determinate, terminal, clustered at the apex of conidiophores, obovate, ellipsoidal, clavate or reniform, smooth, subhyaline, 13-20 × 3.5-11.5 $\mu \mathrm{m}$. Conidia aggregated in large, slimy, black and glistening heads, acrogenous, simple, sphaerical, tuberculate, dark brown, unicellular, $18-23 \mu \mathrm{m}(\bar{x}=20.6 \mu \mathrm{m}, \mathrm{n}=35)$ diam.

Material examined - THAILAND, Chiang Rai Province, Wiang Chai District, Pha Chang, 19'49'52.44", 10001'30.64", on decaying wood, 18 May 2015, Chuan-Gen Lin, PCP 9-33-1 (MFLU 15-3267), living culture MFLUCC 15-0660. 


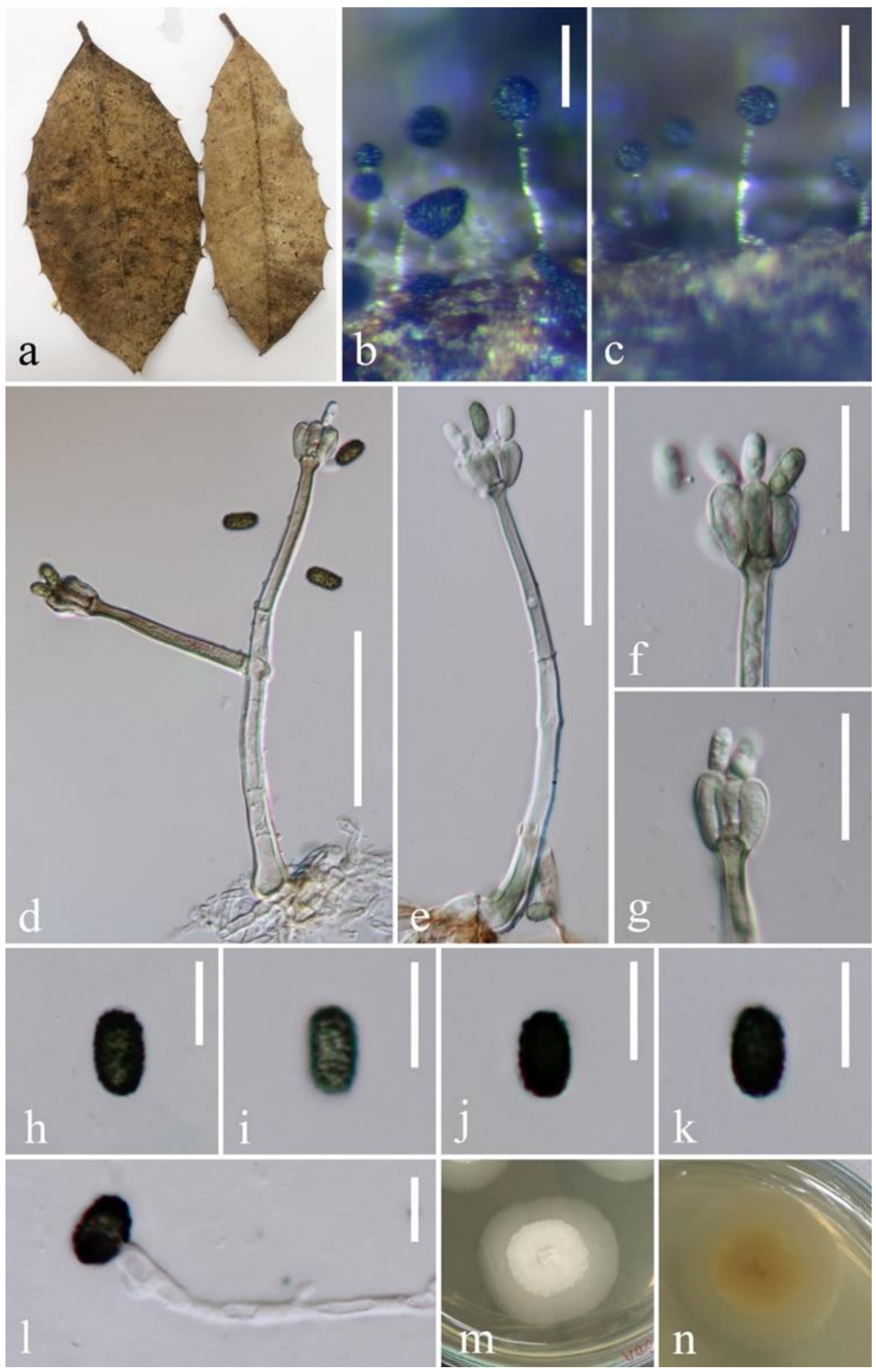

Fig. 3 - Memnoniella oblongispora (MFLU 15-3269, holotype) a. Host leaves. b-c. Conidiophores on the host surface. $\mathbf{d}-\mathbf{e}$. Conidiophores and conidia. $\mathbf{f}-\mathbf{g}$. Conidiogenous cells and conidia. h-k. Conidia. l. Germinating conidium. $\mathbf{m}-\mathbf{n}$. 25-day old colonies on PDA, $\mathrm{m}$ from above, $\mathrm{n}$ from below. - Scale bars: $\mathrm{b}-\mathrm{c}=100 \mu \mathrm{m}, \mathrm{d}-\mathrm{e}=50 \mu \mathrm{m}, \mathrm{f}-\mathrm{g}=20 \mu \mathrm{m}, \mathrm{h}-\mathrm{l}=10 \mu \mathrm{m}$. 
Notes - The specimen observed in this study agrees with the descriptions given in the literature (Subramanian 1957, Izabel et al. 2010). Memnoniella nilagirica is characterized by having large globose and tuberculate conidia. Several species of Stachybotrys s.l. produce globose conidia. However, M. nilagirica produces larger conidia (18-23.2 $\mu \mathrm{m})$ (Subramanian 1957, Wang et al. 2015), which distinguishes it from M. leprosa R.F. Castañeda (7-12 $\mu \mathrm{m})$ (Wang et al. 2015), M. stilboidea Munjal \& J.N. Kapoor (4-5.5 $\mu$ m, also developing synnemata) (Ellis 1976), S. crassa Marcha (16-18 $\mu \mathrm{m})$ (Wang et al. 2015), S. globosa P.C. Misra \& S.K. Srivast.(4.5-8 $\mu \mathrm{m})$ (Misra \& Srivastava 1982), S. jiangziensis Y.M. Wu \& T.Y. Zhang (6-9 $\mu \mathrm{m})(\mathrm{Wu} \&$ Zhang 2010), $S$. mexicanus J. Mena \& Heredia (9-12.5 $\mu \mathrm{m}$, colorless) (Wang et al. 2015), S. microspora (B.L. Mathur \& Sankhla) S.C. Jong \& E.E. Davis (5-6 $\mu \mathrm{m})$ (Jong \& Davis 1976), S. ruwenzoriensis Matsush $(6-8 \mu \mathrm{m})$ (Matsushima 1985), S. sphaerospora Morgan-Jones \& R.C. Sinclair $(11-12 \mu \mathrm{m})$ (Morgan-Jones \& Sinclair 1980), S. subreniformis Q.R. Li \& Y.L. Jiang (6-9.5 × 4.5-7.5 $\mu \mathrm{m})(\mathrm{Li}$ \& Jiang 2011) and S. variabilis H.F. Wang \& T.Y. Zhang $(4-20 \times 3-13 \mu \mathrm{m})$ (Wang \& Zhang 2009).

Memnoniella nilagirica (MFLUCC 15-0660) forms a clade together with the strains of $M$. pseudonilagirica L. Lombard \& Crous (CBS 136405) with 98\% MP bootstrap support, 100\% ML bootstrap support and 100\% Bayesian posterior probabilities within the Memnoniella clade (Fig. 1). Memnoniella pseudonilagirica, which is morphologically similar to $M$. nilagirica, was introduced by Lombard et al. (2016). It can be distinguished from $M$. nilagirica by its longer conidiophores and smaller conidia (Lombard et al. 2016).

Accordingly, in this study, we propose the synonymy of Stachybotrys nilagirica, under the new combination Memnoniella nilagirica, based on its morphology and phylogenetic analysis (Fig. 1). This is the first report of M. nilagirica in Thailand. We also provide ITS, SSU, LSU, RPB2 and TEF1 sequence data.

Stachybotrys microspora (B.L. Mathur \& Sankhla) S.C. Jong \& E.E. Davis, Mycotaxon 3(3): 448 (1976)

三Stachybotrys atra var. microspora B.L. Mathur \& Sankhla, Sci. Cult.: 93 (1966)

Colonies on MEA effuse, hairy, circular, grey to dark on top side, light yellow to dark on reverse, attaining a diameter of $2-2.5 \mathrm{~cm}$ in 14 days at $25^{\circ} \mathrm{C}$. Mycelium mostly superficial. Sexual morph: Undetermined. Asexual morph: Hyphomycetous. Conidiophores macronematous, mononematous, erect, simple, straight or flexuous, irregularly branched or sympodially branched, sometimes unbranched, smooth, often covered with dark granules near the apex, thick-walled, septate, branches of the conidiophore hyaline at the base, dark grey at the apex, bearing at its apex a crown of phialides, $29-61 \mu \mathrm{m}$ long $(\bar{x}=38.9 \mu \mathrm{m}, \mathrm{n}=26), 2.5-4.5 \mu \mathrm{m}$ wide $(\bar{x}=3.4 \mu \mathrm{m}, \mathrm{n}=39)$ at the base, tapering to $1-2.5 \mu \mathrm{m}$ wide $(\bar{x}=1.7 \mu \mathrm{m}, \mathrm{n}=23)$ near the apex. Conidiogenous cells monophialidic, discrete, determinate, terminal, clustered at the apex of conidiophores, obovoid, the outer ones somewhat curved, smooth, light grey, 6-9.5 $\mu \mathrm{m}$ long $(\bar{x}=7.2 \mu \mathrm{m}, \mathrm{n}=37), 3-5 \mu \mathrm{m}$ wide $(\bar{x}=4.1 \mu \mathrm{m}, \mathrm{n}=35)$ at the widest point. Conidia unicellular aggregated in large, slimy, black and glistening heads, acrogenous, simple, when young elliptical or pyriform, rounded at the apex and rounded or truncate at the base, $5.5-8 \mu \mathrm{m}$ long $(\bar{x}=6.9 \mu \mathrm{m}, \mathrm{n}=37), 3-4.5 \mu \mathrm{m}$ wide $(\bar{x}=3.9 \mu \mathrm{m}, \mathrm{n}$ $=38)$, becoming globose, $4-6 \mu \mathrm{m}(\bar{x}=5.2 \mu \mathrm{m}, \mathrm{n}=50)$ in diameter at maturity, roughened, dark olive grey to black.

Material examined - Thailand, Prachuap Khiri Khan, Khao Lom Muak, 1147'3.96"$11^{\circ} 47^{\prime} 11.24^{\prime \prime N}$, 99 $48^{\prime} 49.13^{\prime \prime}-99^{\circ} 49^{\prime} 0.63 " \mathrm{E}$, on decaying wood, 29 July 2015, Chuan-Gen Lin, KLM 3-2 (MFLU 15-3270), living culture MFLUCC 15-0830; Thailand, Prachuap Khiri Khan,

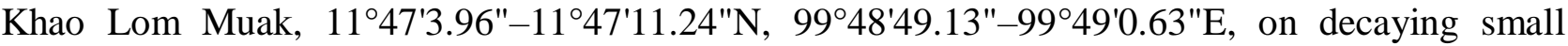
shrubs, 29 July 2015, Chuan-Gen Lin, KLM 16-1 (MFLU 16-0883), living culture MFLUCC 151076.

Notes - Among the species that produce more or less globose or sphaerical conidia, $M$. nilagirica and S. globosa P.C. Misra \& S.K. Srivast. are most similar to S. microspora. Memnoniella nilagirica has larger globose conidia $(18-23 \mu \mathrm{m})$, but $S$. globosa is very similar to $S$. 


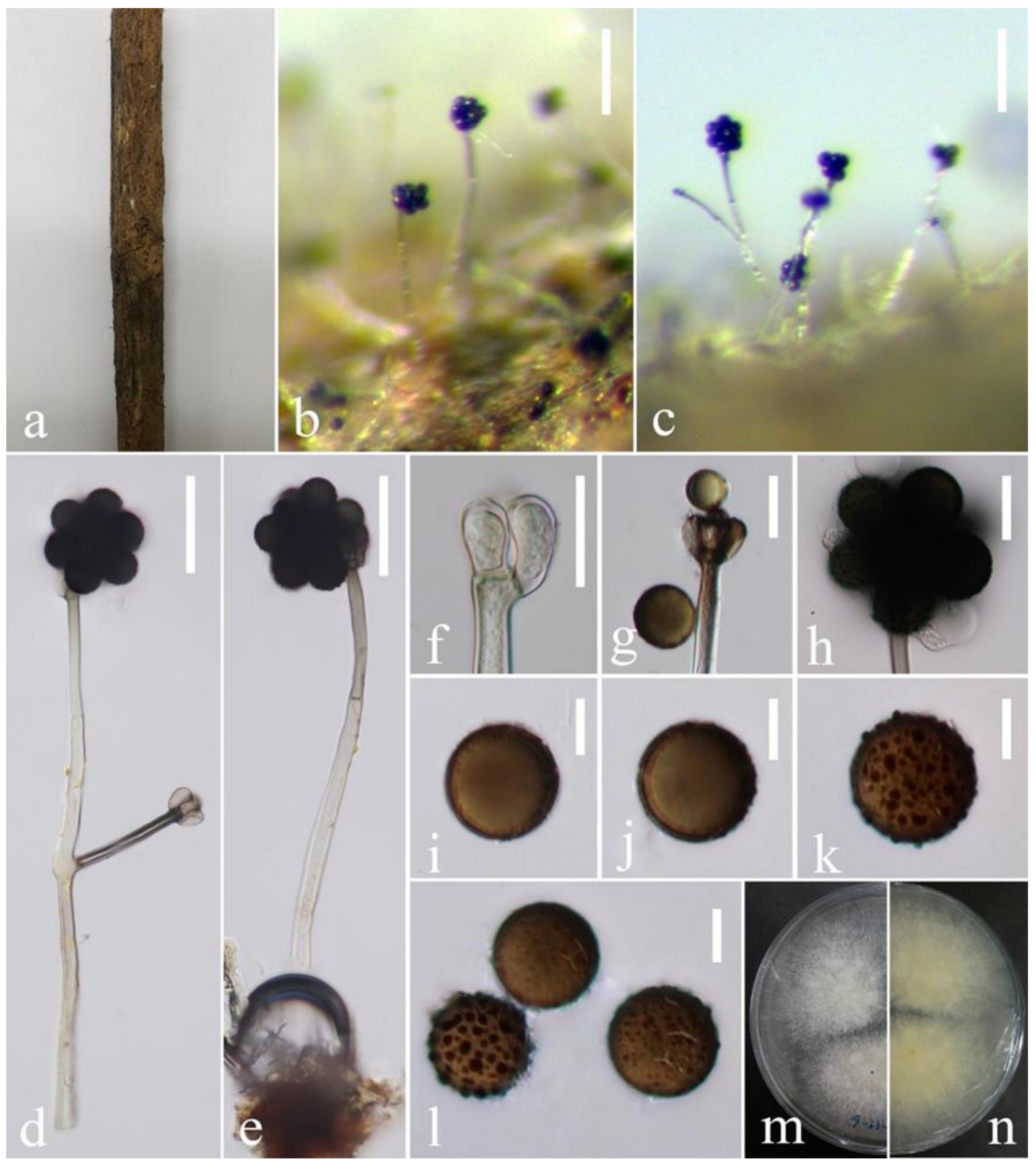

Fig. 4 - Memnoniella nilagirica (MFLU 15-3267) a. Host material, b, c. Conidiophores on the host surface. d, e. Conidiophores and conidia. $\mathbf{f}-\mathbf{h}$. Conidiogenous cells and conidia. $\mathbf{i}-\mathbf{l}$. Conidia. m, n. 28-day old colonies on PDA, $\mathrm{m}$ from above, $\mathrm{n}$ from below. - Scale bars: $\mathrm{b}-\mathrm{c}=100 \mu \mathrm{m}, \mathrm{d}-\mathrm{e}=$ $50 \mu \mathrm{m}, \mathrm{f}-\mathrm{h}=20 \mu \mathrm{m}, \mathrm{i}-\mathrm{l}=10 \mu \mathrm{m}$.

microspora in that it produces elliptical or pyriform conidia when young that become globose at maturity. Because of the similarity in the conidial shape and size between $S$. microspora and $S$. globosa (4.5-8 $\mu \mathrm{m}$ ) (Misra \& Srivastava 1982), Wang et al. (2015) proposed these two species should be further studied to determine if they are conspecific. This is the first report of $S$. microspora in Thailand. 

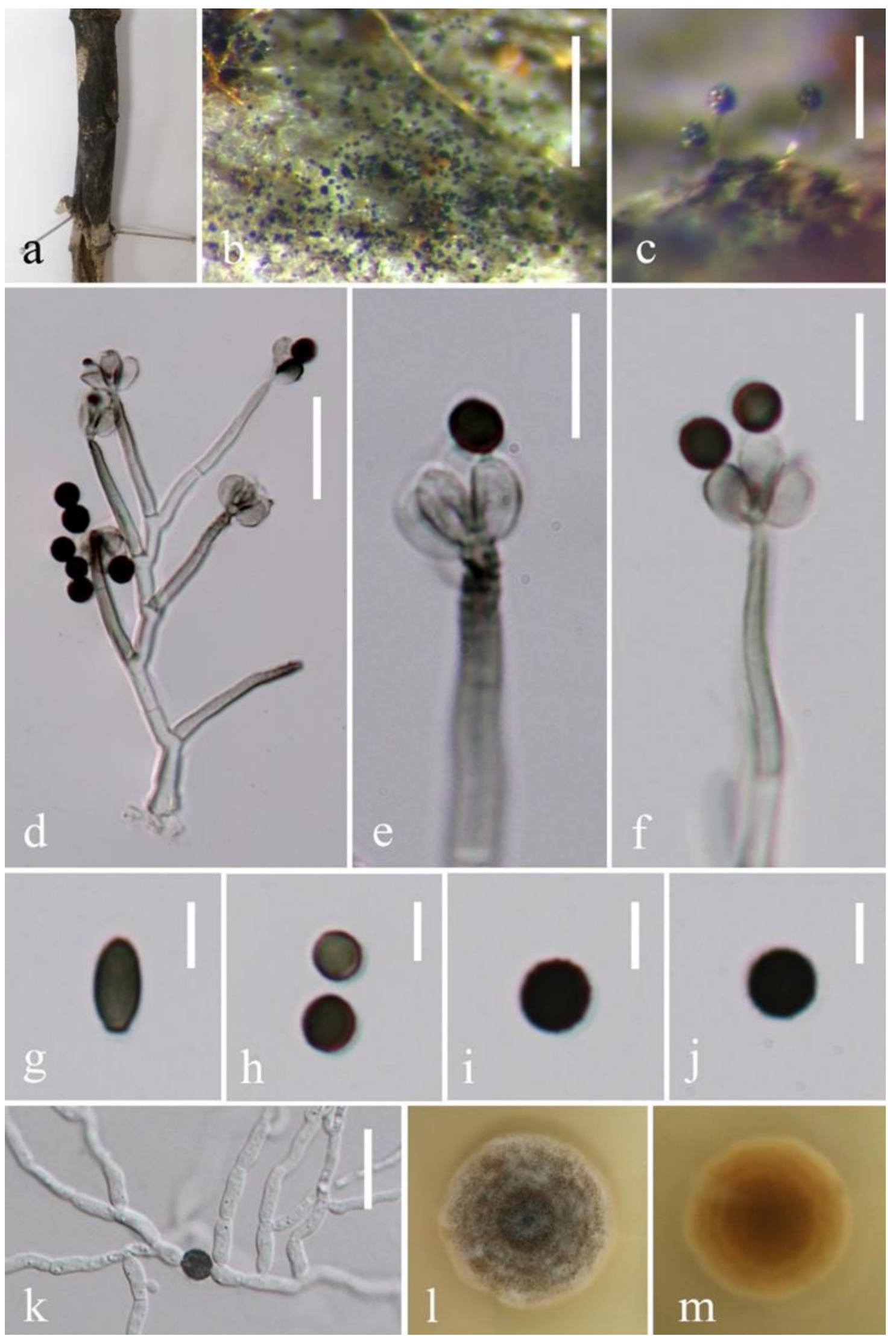

Fig. 5 - Stachybotrys microspora (MFLU 15-3270) a. Host. b, c. Conidiophores on the host surface. d. Conidiophores and conidia. e, f. Conidiogenous cells and conidia. $\mathbf{g}-\mathbf{j}$. Conidia. k. Germinating conidium. $\mathbf{l}$, m. 10-day old colonies on MEA, 1 from above, $\mathrm{m}$ from below. - Scale bars: $\mathrm{b}=500 \mu \mathrm{m}, \mathrm{c}=100 \mu \mathrm{m}, \mathrm{d}=20 \mu \mathrm{m}, \mathrm{e}-\mathrm{f}=10 \mu \mathrm{m}, \mathrm{g}-\mathrm{j}=5 \mu \mathrm{m}, \mathrm{k}=20 \mu \mathrm{m}$. 
Annotated checklist of stachybotrys-like fungi in Thailand

Brevistachys subsimplex (Cooke) L. Lombard \& Crous, in Lombard, Houbraken, Decock, Samson, Meijer, Réblová, Groenewald \& Crous, Persoonia 36: 185 (2016)

On Thysanoleana latifolia, Doi Suthep-Pui National Park (Bhilabutra et al. 2010).

On Musa acuminata, Doi Suthep Pui National Park (Photita et al. 2003b, Farr \& Rossman 2015).

Cymostachys garethjonesii C.G. Lin, Yong Wang bis \& K.D. Hyde

On decaying Dracaena sp. leaf, Khao Lan, Bang Saphan District, Prachuap Khiri Khan (This study).

Memnoniella dichroa (Grove) L. Lombard \& Crous, in Lombard, Houbraken, Decock, Samson, Meijer, Réblová, Groenewald \& Crous, Persoonia 36: 196 (2016)

On Musa acuminata, Thailand (Photita et al. 2003a, Farr \& Rossman 2015).

Memnoniella echinata (Riv.) Galloway, Trans. Brit. Mycol. Soc.18: 165. (1933)

On Delonix regia, Khao Yai National Park (Somrithipol et al. 2002).

On cow dung, Saraburi, Maung District, KUFC 3089 (Jeamjitt et al. 2006).

On decaying leaves of Dracaena lourieri, Chiangdao National Park, Chiang Mai Province (Thongkantha et al. 2008).

On Thysanoleana latifolia, Doi Suthep-Pui National Park (Bhilabutra et al. 2010).

Memnoniella levispora Subram., J. Indian bot. Soc. 33: 40 (1954)

On dead twig of T. grandis, Mae Chan District, Chiang Rai Province (Doilom et al. 2017).

Memnoniella nilagirica (Subram.) C.G. Lin, Yong Wang bis \& K.D. Hyde

On decaying wood, Pha Chang Park, Wiang Chai District, Chiang Rai Province (This study).

Memnoniella oenanthes (M.B. Ellis) L. Lombard \& Crous, in Lombard, Houbraken, Decock,

Samson, Meijer, Réblová, Groenewald \& Crous, Persoonia 36: 199 (2016)

On fallen leaves of Ficus, Chiang Mai Province (Wang et al. 2008).

Memnoniella oblongispora C.G. Lin, McKenzie, Yong Wang bis \& K.D. Hyde

On decaying Quercus sp. leaf, Ang Kep Nam Wat Tham Khao Hin Phayanak (Wat Tham Sao Hin Payanak), Mae Sai District, Chiang Rai Province (This study).

Stachybotrys albipes (Berk. \& Broome) S.C. Jong \& Davis, Mycotaxon 3(3): 425 (1976) (= Melanopsamma pomiformis)

On palm Eleiodoxa conferta, Sirindhorn Research and Nature Study Center (Sirindhorn Peat Swamp Forest), Narathiwat Province (Pinnoi et al. 2006).

Stachybotrys bambusicola Rifai, Trans. Br. mycol. Soc. 47(2): 270 (1964)

On Licuala longicalycata, Sirindhorn Peat Swamp Forest in southern Thailand $\left(06^{\circ} 12^{\prime} \mathrm{N}\right.$ 101 ${ }^{\circ} 57^{\prime}$ E, elevation 0-4 m) (Pinruan et al. 2007).

Stachybotrys chartarum (Ehrenb.) S. Hughes, Can. J. Bot. 36: 812 (1958)

Cultivated lands soil, Eastern Thailand (Thamsurakul et al. 1985).

On toad dung, Bangkok, Bang Sue District, KUFC 3207 (Jeamjitt et al. 2006).

On Dracaena lourieri, Chiangdao National Park in Chiang Mai Province (Thongkantha et al. 2008).

Stachybotrys elegans (Pidopl.) W. Gams, Compendium of Soil Fungi (London): 746 (1980)

On fallen leaves of Ficus, Chiang Mai Province (Wang et al. 2008).

Stachybotrys microspora (B.L. Mathur \& Sankhla) S.C. Jong \& E.E. Davis, Mycotaxon 3(3): 448 (1976)

On decaying wood, Khao Lom Muak, Prachuap Khiri Khan (This study).

On decaying subshrubs, Khao Lom Muak, Prachuap Khiri Khan (This study).

Stachybotrys nephrospora Hansf., Proc. Linn. Soc. London 155: 45 (1943) [1942-43]

On Musa acuminata, Doi Suthep Pui National Park (Photita et al. 2003b).

On fallen leaves of Ficus, Chiang Mai Province (Wang et al. 2008).

On Musa acuminata, Thailand (Photita et al. 2003a, Farr \& Rossman 2015).

On dead needles of Pinus khasya, Thailand (Tokumasu et al. 1990, Whitton et al. 2001, Farr \& Rossman 2015). 
Stachybotrys palmae Pinruan, in Pinruan, McKenzie, Jones \& Hyde, Fungal Diversity 17: 146 (2004)

On Licuala longicalycata, Sirindhorn Peat Swamp Forest in southern Thailand $\left(06^{\circ} 12^{\prime} \mathrm{N}\right.$ 101 ${ }^{\circ} 57^{\prime}$ E, elevation 0-4 m) (Pinruan et al. 2007).

On decaying rachis of Licuala longicalycata Furtado, Sirindhorn Peat Swamp Forest, Narathiwat, BBH U. Pinruan (Wah 35) (holotype) (Pinruan et al. 2004b).

Stachybotrys parvispora S. Hughes, Mycol. Pap. $48: 74$ (1952)

On Thysanoleana latifolia, Doi Suthep-Pui National Park (Bhilabutra et al. 2010).

On Magnolia liliifera, an evergreen forest in Doi Suthep-Pui, Chiang Mai (N 18 48' 18.73', E 98 54' 47.28', elevation, 107 m) (Monkai et al. 2013).

On Magnolia liliifera, Thailand (Promputtha et al. 2004, Farr \& Rossman 2015).

Stachybotrys renispora P.C. Misra, Mycotaxon 4(1): 161 (1976)

On fallen leaves of Ficus, Chiang Mai Province (Wang et al. 2008).

On dead twig of $T$. grandis, Chiang Dao District, Chiang Mai Province (Doilom et al. 2017)

Stachybotrys ruwenzoriensis Matsush., Matsush. Mycol. Mem. 4: 17 (1985)

On Musa acuminata, Doi Suthep Pui National Park (Photita et al. 2003b).

On Musa acuminata, Thailand (Photita et al. 2003a, Farr \& Rossman 2015).

Stachybotrys sansevieriae G.P. Agarwal \& N.D. Sharma, in Sharma \& Agarwal, J. Indian bot. Soc. 53(1-2): 78 (1974)

On fallen leaves of Ficus, Chiang Mai Province (Wang et al. 2008).

Stachybotrys suthepensis Photita, P. Lumyong, K.D. Hyde \& McKenzie, in Photita, Lumyong, McKenzie, Hyde \& Lumyong, Cryptog. Mycol. 24(2): 149 (2003)

On dead petioles of Musa acuminata, Doi Suthep Pui National Park, PDD 74601 (holotype) (Photita et al. 2003a).

On Musa acuminata, Doi Suthep Pui National Park (Photita et al. 2003b).

Stachybotrys theobromae Hansf., Proc. Linn. Soc. London 155: 45 (1943) [1942-43]

On Musa acuminata, Doi Suthep Pui National Park (Photita et al. 2003b).

On Dracaena lourieri, Chiangdao National Park, Chiang Mai Province (Thongkantha et al. 2008).

On Musa acuminata, Thailand (Photita et al. 2003a, Farr \& Rossman 2015).

\section{Discussion}

In this study, the stachybotrys-like taxa Cymostachys garethjonesii, Memnoniella oblongispora, M. nilagirica and Stachybotrys microspora were identified from decaying wood and leaf material collected from karst areas in Thailand. Of these, C. garethjonesii and M. oblongispora are new species and $M$. nilagirica is new combination introduced in this study and $M$. nilagirica and S. microspora are new records for Thailand. Meanwhile, Memnoniella nilagirica was sequenced for the first time. An annotated checklist of stachybotrys-like taxa in Thailand totalling 19 species is provided based on previous publications and database.

ITS, SSU, LSU, EF1- $\alpha$ and RPB2 sequence data have been used for the phylogenetic analysis of the stachybotrys-like genera in previous studies (Haugland \& Heckman 1998, Haugland et al. 2001, Koster et al. 2009, Wang et al. 2015). In this study, the phylogeny of selected genera within the family Stachybotryaceae is inferred from sequence data (cmdA, ITS, rpb2, tef1 and tub2) and a phylogenetic tree is provided to infer the phylogenetic position of these four strains within the family Stachybotryaceae. Within the genera Stachybotrys s.l. and Memnoniella, several species are problematic, thus in need of further study. For example, the type species $S$. chartarum is a species complex.

Several asexual / sexual connections have been reported for Stachybotrys species. Melanopsamma pomiformis (Pers.) Sacc. was reported to have an S. albipes (Berk. \& Broome) S.C. Jong \& Davis asexual morph (Booth 1957). Stachybotrys gamsii (K.D. Hyde et al.) Yong Wang bis, et al. was reported to have a Didymostilbe aurantiospora Seifert \& G. Okada asexual morph (Hyde et al. 1999). The connections of asexual / sexual of Ornatispora nepalensis Whitton et al. - 
Stachybotrys nepalensis and Ornatispora nova-zealandiae Whitton et al. - S. freycinetiae McKenzie were reported, as both specimens from Pandanaceae were surrounded by a hyphal subiculum made of fertile Stachybotrys conidiophores, in addition, the setae of Ornatispora nepalensis can become fertile conidiophores of Stachybotrys species surrounding the ascomata (Whitton et al. 2012, Wang et al. 2015). Wang et al. (2015) therefore synonymized Ornatispora nepalensis and Ornatispora nova-zealandiae under Stachybotrys. Now Stachybotrys comprises several genera these taxa need recollecting and sequencing to establish their affinities.

\section{Acknowledgements}

This paper is dedicated to Professor E.B. Gareth Jones in celebration of his $80^{\text {th }}$ birthday and thanking him for his contribution to mycology. We would like to thank Prof. Shaun Pennycook (Landcare Research Manaaki Whenua, New Zealand) for advising on the fungal names. The research is supported by the National Natural Science Foundation of China (No. NSFC 31560489), the International Scientific Cooperated Project of Guizhou Province (No[2013]7004, Fundamental Research on Science and Technology, Ministry of Science and Technology of China (2014FY120100), and the grant [JD2014018] from Education Department of Guizhou Province.

\section{References}

Altschul SF, Gish W, Miller W, Myers EW, Lipman DJ. 1990 - Basic local alignment search tool. Journal of Molecular Biology 215, 403-410.

Bhilabutra W, McKenzie E, Hyde K, Lumyong S. 2010 - Fungi on the grasses, Thysanolaena latifolia and Saccharum spontaneum, in northern Thailand. Mycosphere 1, 301-314.

Bisby G. 1943 - Stachybotrys. Transactions of the British Mycological Society 26, 133-143.

Bisby G. 1945 - Stachybotrys and Memnoniella. Transactions of the British Mycological Society 28, 11-12.

Bisby GR, Ellis MB. 1949 - Stachybotrys dichroa Grove. Transactions of the British Mycological Society $32,158-161$.

Booth C. 1957 - Studies of Pyrenomycetes. I. Four species of Chaetosphaeria, two with Catenularia conidia. II. Melanopsamma pomiformis and its Stachybotrys conidia. Mycological Papers 68, 1-27.

Carbone I, Kohn LM. 1999 - A method for designing primer sets for speciation studies in filamentous ascomycetes. Mycologia 99, 553-556.

Castresana J. 2000 - Selection of conserved blocks from multiple alignments for their use in phylogenetic analysis. Molecular Biology and Evolution 17, 540-552.

Chomnunti P, Hongsanan S, Aguirre-Hudson B, Tian Q et al. 2014 - The sooty moulds. Fungal Diversity 66, 1-36.

Crous PW, Shivas RG, Quaedvlieg W, van der Bank M et al. 2014 - Fungal Planet description sheets: 214-280. Persoonia 32, 184-306.

Doilom M, Dissanayake AJ, Wanasinghe DN, Boonmee S et al. 2017 - Microfungi on Tectona grandis (teak) in Northern Thailand. Fungal Diversity, 1-76, doi:10.1007/s 13225-016-03687.

Ellis MB. 1971 - Dematiaceous Hyphomycetes. Kew, Surrey, England, Commonwealth Mycological Institute.

Ellis MB. 1976 - More Dematiaceous Hyphomycetes. Kew, Surrey, England, Commonwealth Mycological Institute.

Farr DF, Rossman AY. 2015 - Fungal Databases, Systematic Mycology and Microbiology Laboratory, ARS, USDA. Retrieved December 15, 2016, from http://nt.arsgrin.gov/fungaldatabases/.

Ford D, Williams PW. 2007 - Karst hydrogeology and geomorphology. Chichester, England; A Hoboken, NJ, John Wiley \& Sons. 
Glass NL, Donaldson GC. 1995 - Development of primer sets designed for use with the PCR to amplify conserved genes from filamentous ascomycetes. Applied and Environmental Microbiology 61, 1323-1330.

Groenewald JZ, Nakashima C, Nishikawa J, Shin HD et al. 2013 - Species concepts in Cercospora: spotting the weeds among the roses. Studies in Mycology 75, 115-170.

Hall TA. 1999 - BioEdit: a user-friendly biological sequence alignment editor and analysis program for Windows 95/98/NT. Nucleic Acids Symposium Series 41, 95-98.

Haugland RA, Heckman JL. 1998 - Identification of putative sequence specific PCR primers for detection of the toxigenic fungal species Stachybotrys chartarum. Molecular and Cellular Probes 12, 387-396.

Haugland RA, Vesper SJ, Harmon SM. 2001 - Phylogenetic relationships of Memnoniella and Stachybotrys species and evaluation of morphological features for Memnoniella species identification. Mycologia 93, 54-65.

Hyde KD, Goh TK, Taylor JE, Fröhlich J. 1999 - Byssosphaeria, Chaetosphaeria, Niesslia and Ornatispora gen. nov., from palms. Mycological Research 103, 1423-1439.

Izabel TdSS, Cruz ACRd, Barbosa FR, Ferreira SML et al. 2010 - The genus Stachybotrys (anamorphic fungi) in the semi-arid region of Brazil. Brazilian Journal of Botany 33, 479487.

Jayasiri SC, Hyde KD, Ariyawansa HA, Bhat J et al. , Buyck B, Cai L, Dai Y-C, Abd-Elsalam KA, Ertz D, Hidayat I, Jeewon R, Jones EBG, 2015 - The Faces of Fungi database: fungal names linked with morphology, phylogeny and human impacts. Fungal Diversity 74, 3-18.

Jeamjitt O, Manoch L, Visarathanonth N, Chamswarng C. 2006 - Diversity and distribution of hyphomycetes from dung in Thailand. Kasetsart Journal, Natural Sciences 40, 890-901.

Jie CY, Geng K, Jiang Y-L, Xu JJ et al. 2013 - Stachybotrys from soil in China, identified by morphology and molecular phylogeny. Mycological Progress 12, 693-698.

Jong SC, Davis EE. 1976 - Contribution to the knowledge of Stachybotrys and Memnoniella in culture. Mycotaxon 3, 409-485.

Katoh K, Standley DM. 2013 - MAFFT multiple sequence alignment software version 7: improvements in performance and usability. Molecular Biology and Evolution 30, 772-780.

Koster B, Wong B, Straus N, Malloch D. 2009 - A multi-gene phylogeny for Stachybotrys evidences lack of trichodiene synthase (tri5) gene for isolates of one of three intrageneric lineages. Mycological Research 113, 877-886.

Li DW, Yang CS, Haugland R, Vesper S. 2003 - A new species of Memnoniella. Mycotaxon 85, 253-257.

Li DW, Yang CS. 2004 - Fungal contamination as a major contributor to sick building syndrome. In: Straus D, ed. Advances in Applied Microbiology, Volume 55. San Diego, ElsevierAcademic Press. p. 31-112.

Li Q-R, Jiang Y-L. 2011 - Stachybotrys subreniformis, new from soil in China. Mycotaxon 115, 171-173.

Lian B, Chen Y, Zhu L, Yang R. 2008 - Effect of Microbial Weathering on Carbonate Rocks. Earth Science Frontiers 15, 90-99.

Lombard L, Houbraken J, Decock C, Samson RA et al. 2016 - Generic hyper-diversity in Stachybotriaceae. Persoonia 36, 156-246.

Maharachchikumbura SSN, Hyde KD, Jones EBG, McKenzie EHC et al. 2016 - Families of Sordariomycetes. Fungal Diversity 79, 1-317.

Maharachchikumbura SSN, Hyde KD, Jones EBG, McKenzie EHC et al. 2015 - Towards a natural classification and backbone tree for Sordariomycetes. Fungal Diversity 72, 199-301.

Matsushima T. 1971 - Microfungi of the Solomon Islands and Papua New Guinea. Kobe, Japan, Published by the author..

Matsushima T. 1985 - Matsushima mycological Memoirs No. 04. Kobe, Japan, Published by the author. 
Misra P, Srivastava S. 1982 - Two undescribed Stachybotrys species from India. Transactions of the British Mycological Society 78, 556-559.

Monkai J, Promputtha I, Kodsueb R, Chukeatirote E et al. 2013 - Fungi on decaying leaves of Magnolia liliifera and Cinnamomum iners show litter fungi to be hyperdiverse. Mycosphere 4, 292-301.

Morgan-Jones G, Sinclair R. 1980 - Notes on hyphomycetes: XXXIII. Stachybotrys sphaerospora sp. nov. from South Africa. Mycotaxon 10, 372-374.

Nylander J. 2004 - MrModeltest v2. Program distributed by the author. Evolutionary Biology Centre, Uppsala University.

Page RD. 1996 - TreeView: an application to display phylogenetic trees on personal computers. Computer Applications in the Biosciences 12, 357-358.

Photita W, Lumyong P, Mckenzie EH, Hyde KD, Lumyong S. 2003a - Memnoniella and Stachybotrys species from Musa acuminata. Cryptogamie Mycologie 24, 147-152.

Photita W, Lumyong P, McKenzie EHC, Hyde KD, Lumyong S. 2003b - Saprobic fungi on dead wild banana. Mycotaxon 85, 345-356.

Pinnoi A, Lumyong S, Hyde KD, Jones EBG. 2006 - Biodiversity of fungi on the palm Eleiodoxa conferta in Sirindhorn peat swamp forest, Narathiwat, Thailand. Fungal Diversity 22, 205218.

Pinruan U, Hyde KD, Lumyong S, McKenzie EHC, Jones EBG. 2007 - Occurrence of fungi on tissues of the peat swamp palm Licuala longicalycata. Fungal Diversity 25, 157-173.

Pinruan U, McKenzie EHC, Jones EBG, Hyde KD. 2004a - Two new species of Stachybotrys, and a key to the genus. Fungal Diversity 17, 145-157.

Promputtha I, Lumyong S, Lumyong P, McKenzie E, Hyde KD. 2004 - Fungal saprobes on dead leaves of Magnolia liliifera (Magnoliaceae) in Thailand. Cryptogamie Mycologie 25, 315321.

Rehner S. Primers for Elongation Factor 1- $\alpha$ (EF1- $\alpha)$. Available from: http://www.aftol.org/pdfs/EF1 primer.pdf.

Ronquist F, Teslenko M, van der Mark P, Ayres DL et al. 2012 - MrBayes 3.2: efficient Bayesian phylogenetic inference and model choice across a large model space. Systematic Biology 61, 539-542.

Seifert KA, Morgan-Jones G, Gams W, Kendrick B. 2011 - The genera of hyphomycetes. Utrecht, The Netherlands, CBS-KNAW Fungal Biodiversity Centre.

Silvestro D, Michalak I. 2012 - raxmlGUI: a graphical front-end for RAxML. Organisms Diversity and Evolution 12, 335-337.

Somrithipol S, Jones EBG, Hywel-Jones NL. 2002 - Fungal diversity and succession on pods of Delonix regia (Leguminosae) exposed in a tropical forest in Thailand. Fungal Diversity 10, 131-139.

Subramanian CV. 1957 - Hyphomycetes-IV. Proceedings of The Indian Academy of Sciences Section B 46, 324-335.

Swofford DL. 2002 - PAUP*: Phylogenetic Analysis Using Parsimony and other methods, version 4.0 b10. Sunderland, MA: Sinauer Associates.

Tamura K, Stecher G, Peterson D, Filipski A, Kumar S. 2013 - MEGA6: Molecular Evolutionary Genetics Analysis version 6.0. Molecular Biology and Evolution 30, 2725-27229.

Tang AMC, Hyde KD, Corlett RT. 2003 - Diversity of fungi on wild fruits in Hong Kong. Fungal Diversity 14, 165-185.

Thamsurakul S, Manoch L, Pupipat U. 1985 - Comparative studies on micro-fungi of cultivated and forest soils in eastern Thailand. 23 National Conference: Poster Session, Bangkok (Thailand), 4-7 February 1985.

Thongkantha S, Lumyong S, McKenzie EHC, Hyde KD. 2008 - Fungal saprobes and pathogens occurring on tissues of Dracaena lourieri and Pandanus spp. in Thailand. Fungal Diversity 30, 149-169. 
Tokumasu S, Tubaki K, Manoch L. 1990 - A preliminary list of hyphomycetes isolated from pine leaf litter of Thailand. Reports of the Tottori Mycological Institute (Japan).

Viles H. 1984 - Biokarst: review and prospect. Progress in Physical Geography 8, 523-542.

Vilgalys R, Hester M. 1990 - Rapid genetic identification and mapping of enzymatically amplified ribosomal DNA from several Cryptococcus species. Journal of Bacteriology 172, 42384246.

Wang H, Zhang T. 2009 - Notes on soil dematiaceous hyphomycetes from the QaidamBasin, Qinghai Province, China. Mycosystema 28, 20-24.

Wang HK, Hyde KD, Soytong K, Lin FC. 2008 - Fungal diversity on fallen leaves of Ficus in northern Thailand. Journal of Zhejiang University Science B 9, 835-841.

Wang Y, Hyde KD, McKenzie EHC, Jiang YL et al. 2015 - Overview of Stachybotrys (Memnoniella) and current species status. Fungal Diversity 71, 17-83.

White TJ, Bruns T, Lee S, Taylor J. 1990 - Amplification and direct sequencing of fungal ribosomal RNA genes for phylogenetics. In: Innis MA, Gelfand DH, Sninsky JJ, White TJ, eds. PCR protocols: a guide to methods and applications. California, Academic Press. pp 315-322.

Whitton SR, McKenzie EHC, Hyde KD. 2001 - Microfungi on the Pandanaceae: Stachybotrys, with three new species. New Zealand Journal of Botany 39, 489-499.

Whitton SR, McKenzie EHC, Hyde KD. 2012 - Fungi Associated with Pandanaceae. Springer Netherlands.

Wu YM, Zhang TY. 2010 - Two new species of Stachybotrys from soil. Mycotaxon 114, 459-462. 